Kazimierz Skoczylas*

Toruń

\title{
Odniesienia młodzieży do religii katolickiej na Kujawach wschodnich
}

W życiu każdej społeczności obecne są wartości szczególnie dla niej ważne. Są one pielęgnowane i przekazywane kolejnym pokoleniom. Młode pokolenie w Polsce na początku XXI wieku dorasta w szybko zmieniającym się świecie. To wywołuje określone przemiany zarówno w świadomości społecznej, jak i myśleniu i zachowaniu poszczególnych jednostek. Oddziałuje także w pewnym zakresie na postawy wobec religii. Na dokonujące się zmiany podatna jest szczególnie młodzież. Stąd pojawia się pytanie, jakie jest odniesienie młodzieży z Kujaw wschodnich, wychowującej się w rodzinach katolickich, do wybranych wartości religijno-moralnych obecnych w religii katolickiej.

\section{Kształtowanie się stosunku młodzieży do wartości}

Młodość jest okresem przechodzenia od dzieciństwa do dorosłości. Okres ten charakteryzuje się własną odrębnością i specyfiką powiązaną z dotychczasowymi doświadczeniami wychowanka. Przebieg tego rozwoju wyznacza dalszy jego kierunek, a potem sposób funkcjonowania jednostki

* Ks. dr hab. Kazimierz Skoczylas jest adiunktem w Wydziale Teologicznym Uniwersytetu Mikołaja Kopernika w Toruniu, w Katedrze Teologii Praktycznej. Adres: Wydział Teologiczny UMK, ul. Gagarina 37, 87-100 Toruń; e-mail: skoczyka@umk.pl. 
w społeczeństwie i kulturze ${ }^{1}$. Ten okres jest również czasem kształtowania indywidualnego stosunku do wartości. W tym czasie wiele wartości przyjętych przez wychowanie w rodzinie ${ }^{2} \mathrm{i}$ w innych kręgach wychowawczych podlega wartościowaniu. Jedne wartości są przyjmowane, a inne są odsuwane lub wyłączane $\mathrm{z}$ własnego systemu wartości. Podobny proces dokonuje się wobec wartości, które są przekazywane czy podkreślane przez różne instytucje wychowawcze czy wspólnoty religijne. Współczesna młodzież kształtuje swój świat wartości poprzez odniesienie do silnych trendów kulturowych oraz przez wymianę poglądów na forach internetowych ${ }^{3}$. Na jej stosunek do wartości ma wpływ także moda i różne kampanie społeczne w mediach. One podsuwają jej, przez różne formy reklamy, dobra konsumpcyjne. Reklama uczestniczy też w kreowaniu potrzeby posiadania. Na skutek jej odziaływania młodzi chcą coraz więcej posiadać ${ }^{4}$. Jednocześnie nastawienie konsumpcyjne zamyka młodzież na wszystko, co konfrontuje z takimi doświadczeniami jak śmierć, cierpienie, nieszczęście. Wypiera je ze swojej świadomości. Wrogiem posiadania jest moralność. Aby ograniczyć jej oddziaływanie na własną świadomość, młodzież próbuje relatywizować normy moralne ograniczające chęć posiadania ${ }^{5}$.

Czas młodości jest też okresem kształtowania osobistego odniesienia do religii. Dzieje się to zwykle w dłuższym procesie. Gdy młodzi rodzą się w rodzinach praktykujących swoją religię, to zwykle od wczesnego dzieciństwa następuje stopniowe wprowadzenie ich w jej praktykowanie. Systematyczne wprowadzenie w życie religijne łączy się z otwieraniem na wartości i ich przyjmowaniem. Jeśli rodzina stworzyła takie możliwości, że dzieci poznały wartości ważne dla religii i zarazem ważne dla rodziny, a tym samym

1 Por. Jolanta Kędzior, „Młodzież jako specyficzna kategoria społeczna”, w: Wspótczesna młodzież pomiędzy eros a thanatos, red. Jacek Kurzępa, Alicja Lisowska, Agnieszka Pierzchalska (Wrocław: Agencja Wydawnicza „ARGI” s.c., 2008), 9-18.

2 Por. Leon Dyczewski, Rodzina, społeczeństwo, państwo (Lublin: Towarzystwo Naukowe Katolickiego Uniwersytetu Lubelskiego, 1994), 107.

3 Por. Grzegorz Godawa, „Emocjonalne dojrzewanie dzieci i młodzieży w medialnym społeczeństwie”, Studia Socialia Cracoviensia 2 (2013): 111-125.

${ }^{4}$ Por. Marek Ejsmont, Barbara Kosmalska, ,Reklamy a postawy konsumpcyjne dzieci i młodzieży”, w: Wspótczesna młodzież pomiędzy eros a thanatos, red. Jacek Kurzępa, Alicja Lisowska, Agnieszka Pierzchalska (Wrocław: Agencja Wydawnicza „ARGI” s.c., 2008), 95-104.

${ }^{5}$ Por. Longina Strumska-Cylwik, „Młodzież w dobie kultury przyzwolenia oraz otwartości «niepohamowanej»/«obojętnej» (pytanie o otwartość w kontekście zjawisk konsumpcjonizmu i konsumeryzmu)", w: Współczesna młodzież pomiędzy eros a thanatos, red. Jacek Kurzępa, Alicja Lisowska, Agnieszka Pierzchalska (Wrocław: Agencja Wydawnicza „ARGI” s.c., 2008), 87. 
przez nią respektowane, to one stanowią pewien element sytemu moralnego określającego, co jest ważne dla tych osób. Jeśli przyjmowanie tych wartości łączy się z pozytywnym przeżywaniem ich, to stanowią one ważny element dziedzictwa wyniesionego $\mathrm{z}$ rodziny. W przyszłości przez pryzmat tych wartości będą wartościowały wszystkie wpływy zewnętrzne ${ }^{6}$.

Rodzina tworzy także własną kulturę. Żyjąc w określonym społeczeństwie, korzysta z jego kultury. Chcąc normalnie funkcjonować, przejmuje z kultury społeczeństwa podstawowe wartości, normy, wzory zachowań, historię, przestrzega obowiązujących praw, obyczajów, korzysta z funkcjonujących instytucji. Może to wszystko wykorzystywać dla swego funkcjonowania i może je przekazać kolejnemu pokoleniu. Dzięki temu istnieje pewna ciągłość kulturowa. Jednakże w życiu domowym rodzina może pielęgnować wytwory kultury i wzory zachowań, które są odmienne od dominującej kultury społeczeństwa. Zazwyczaj tak postępują rodziny chińskie, muzułmańskie czy żydowskie, które żyją w diasporze. $Z$ tego też powodu kultura rodziny może być odmienna od kultury społeczeństwa. $Z$ tego powodu rodziny te mogą cieszyć się uznaniem albo być lekceważone w społeczeństwie. Rodziny w życiu domowym zazwyczaj pielęgnują kulturę grupy etnicznej lub religijnej, z którą się identyfikują ${ }^{7}$.

Szczególne znaczenie dla przeżywania wartości w życiu rodzinnym ma świętowanie. Wśród wielu świat są też święta niosące treści religijne. W kręgu rodzin chrześcijańskich każde ważniejsze wydarzenie z życia Jezusa i Maryi jest treścią święta chrześcijańskiego. We wspólnocie religijnej i rodzinnej każda ważniejsza prawda religijna jest również świętowana. Od początku chrześcijaństwa cyklicznie świętowana jest niedziela jako dzień radości ze Zmartwychwstania Chrystusa. Punktem centralnym święta jest uczestnictwo w Eucharystii. Zaś owocem świętowania jest głębokie poczucie wspólnoty, jedność i radość. Świętowanie łączy się od starożytności chrześcijańskiej z czasem wolnym od pracy ${ }^{8}$.

Należy zauważyć, że świętowanie oznacza podkreślenie wartości w życiu indywidualnym i społecznym. W centrum świętowania stoi zawsze jakaś wartość cenna dla rozwoju i życia jednostki, rodziny, społeczeństwa, narodu czy państwa. Ci, co świętują, pozostawiają wszystko, czym żyją na co dzień,

${ }^{6}$ Por. Leon Dyczewski, Rodzina twórca i przekazicielem kultury (Lublin: Towarzystwo Naukowe Katolickiego Uniwersytetu Lubelskiego, 2003), 39-41.

7 Tamże, 28.

${ }^{8}$ Por. Leon Dyczewski, „Święto i jego kulturotwórcza rola”, Kultura i społeczeństwo 2 (2012): 3-16. 
aby przeżywać to, co dla nich ważne i cenne. Święto religijne przypomina o wartościach najwyższych i tworzy atmosferę sprzyjającą ich uświadomieniu i przeżywaniu. Dzięki niemu możliwe jest odnowienie przekonań religijnych, prawd wiary, norm etycznych. To wszystko wzmacnia obrany kierunek działań jednostek, rodzin i społeczności. Stanowi podstawę wspólnego wartościowania9.

\section{Charakterystyka środowiska badanej młodzieży}

Młodzież Kujaw wschodnich żyje na terenie, który obejmuje tę część Kujaw, która w wyniku rozbiorów należała do zaboru rosyjskiego. Ta część Kujaw pokrywa się z północną częścią Diecezji Włocławskiej. Jest to teren między Lubieniem Kujawskim a Aleksandrowem Kujawskim oraz między Włocławkiem w północnej części tego regionu a Izbicą Kujawską i Sompolnem na południu. Dominującą aglomeracją miejską dla tego regionu jest Włocławek. On skupia wieloraką aktywność mieszkańców tego regionu.

Wartości młodego pokolenia są zakorzenione w świece wartości ważnych dla starszego pokolenia. Są to wartości, które łączą się z historią tego regionu. Teren Kujaw wschodnich był areną wielu tragicznych wydarzeń historycznych. W wyniku rozbiorów należał do zaboru rosyjskiego. Ludność uczestniczyła w wielkich zrywach narodowych, takich jak powstania: kościuszkowskie, listopadowe i styczniowe ${ }^{10}$.

W starszym pokoleniu są obecne wartości, które wiążą się z religią przez nich praktykowaną, a także z narodowością mieszkańców. W miastach tego regionu mieszkali obok siebie Polacy, Żydzi i Niemcy. W życiu społecznym obecne były wartości ważne dla każdej z tych nacji i wyznania. Żydzi przynieśli ze sobą dostępność do różnych usług przez nich wykonywanych, a Niemcy tworzyli na tym terenie początki uprzemysłowienia.

Na tym terenie od średniowiecza jest obecne chrześcijaństwo. We Włocławku, według bulli papieża Eugeniusza III z roku 1148, istnieje diecezja z wyraźnie określonymi granicami ${ }^{11}$. Działalność duszpasterska realizowana

9 Tamże, 5-6.

${ }^{10}$ Por. Michał Morawski, Monografia Włocławka (Włocławek: Włocławskie Wydawnictwo Diecezjalne, 2003), 379-382.

${ }^{11}$ Por. Witold Kujawski, „Historia Diecezji Włocławskiej”, w: Rocznik Diecezji Włocławskiej, red. Artur Niemira (Włocławek: Wydawnictwo Duszpasterstwa Rolników, 2011), 41-82. 
na tym obszarze przyczyniała się do upowszechniania wartości katolickich przez sieć parafialną i obecność różnych zakonów.

Kujawy to równocześnie teren rolniczy i zakorzenione są na nim wartości związane z rolnictwem. Ten region dawał dobre warunki do uprawy wielu płodów, które przynosiły rolnikom poważne korzyści. Jego położenie w bliskiej obecności Wisły dawało możliwość eksportu nadwyżki zbóż poza ten teren ${ }^{12}$. W XIX wieku dokonał się kolejny skok w rozwoju rolnictwa. Zaczęto tu uprawiać buraki cukrowe. Wraz z tym rozwijał się stopniowo przemysł cukrowniczy. To przymnożyło dochodów w folwarkach szlacheckich. Powstające cukrownie były w tym czasie źródłem postępu technicznego ${ }^{13}$. Koniec XIX wieku i początek XX wieku był czasem upowszechniania się spółdzielczości w różnych zakresach. Wówczas na wsiach na tym terenie żywe były tendencje lewicowe. Warto tu zauważyć społeczną aktywność rodziny Kretkowskich, promującej wartości bliskie chrześcijaństwu. Wyrażało się to w organizacji ochronek, szkół powszechnych, zakładaniu szkół rolniczych, powoływaniu straży ogniowych, wspieraniu działalności kół gospodyń wiejskich, różnych form doskonalenia rolniczego ${ }^{14}$.

Sympatie lewicowe są żywe w ośrodkach przemysłowych oraz na wsi w środowiskach służby folwarcznej. Tam też partie lewicowe szukają poparcia. Przedstawiciele ruchów lewicowych powołali w 1904 roku Żeńską Szkołę Rolniczą w podwłocławskim Kruszynku. Prowadziła ją przez kilka lat Jadwiga Dziubińska ${ }^{15}$. Na wsi w relacjach społecznych widoczne były pewne napięcia. Wynikały one z tego, że znaczna część ziemi znajdowała się w rękach ziemian, a tylko niewielu chłopów posiadało własne gospodarstwa. Znaczna część warstwy chłopskiej należała do służby folwarcznej pracującej w majątkach ziemiańskich. W tej grupie najsilniejszy był głód ziemi ${ }^{16}$.

12 Por. Zenon Guldon, Jadwiga Muszyńska, „Zasięg gdańskiego i królewieckiego rynku zbożowego a rozwój gospodarki folwarczno-pańszczyźnianej w Rzeczypospolitej w XVI-XVIII wieku", Czasy nowożytne 4 (1998): 141-165.

${ }_{13}$ Por. Arkadiusz Ciechalski, „Cukrownia w Choceniu”, http://www.historycznepapiery.pl/ wp-content/uploads/2015/03/A.-Ciechalski-Cukrownia-w-Choceniu.pdf(dostęp: 04.09.2017).

${ }^{14}$ Arkadiusz Ciechalski, „Ziemiańska rodzina Kretkowskich z okręgu kowalskiego”, w: Kowal przez wieki, red. Zdzisław J. Zasada (Włocławek-Kowal: Włocławskie Towarzystwo Naukowe, 2007), 100-101.

${ }_{15}$ Małgorzata Kowalska, Jadwiga Dziubińska, http://kobietynawsi.p1/Jadwiga Dziubińska (dostęp: 20.08.2017).

${ }^{16}$ Por. Bogdan M. Wawrzyniak, Monografia rolnictwa województwa kujawsko-pomorskiego (Włocławek: Lega - Oficyna Wydawnicza Włocławskiego Towarzystwa Naukowego, 2002), 116-118. 
Dla regionu Kujaw wschodnich istotne znaczenie ma Włocławek. Jedną $\mathrm{z}$ cech charakterystycznych tego miasta jest skupienie na jego terenie znaczącej liczby szkół średnich. Zjawisko to było obecne już w okresie międzywojennym. Szkoły średnie rozwinęły się tutaj dość intensywnie po odzyskaniu przez Polskę niepodległości ${ }^{17}$. Natomiast po drugiej wojnie światowej miasto się rozrastało i zwiększała się w nim liczba szkół.

Na koniec XX wieku miasto Włocławek osiągnęło około 120 tys. mieszkańców. Wzrosła też liczba szkół średnich. Oprócz istniejących powstawały nowe szkoły ogólnokształcące i szkoły techniczne. Służyły one zarówno młodzieży Włocławka, jak i całemu regionowi Kujaw wschodnich. W roku 2012 było we Włocławku 11 dużych zespołów szkół średnich.

Poglądy młodzieży z Kujaw Wschodnich pozwolił poznać sondaż diagnostyczny. Został on zrealizowany wśród młodzieży uczącej się w szkołach Włocławka w maju 2012 roku. Badana młodzież należy do wyznania katolickiego. Wychowuje się w rodzinach, gdzie przywiązanie do wiary jest nadal dość silne ${ }^{18}$. Wśród respondentów 65,2\% stanowią licealiści, a 34,8\% młodzieży uczy się w różnych typach szkół zawodowych. Gdy weźmiemy pod uwagę miejsce zamieszkania, to $39,1 \%$ mieszka na wsi, $13,7 \%$ w małym mieście, $14,8 \% \mathrm{w}$ średnim mieście, $32,4 \%$ zaś w dużym mieście ${ }^{19}$.

\section{Odniesienie się badanych do wybranych wartości religijno-moralnych}

Szczególne znaczenie dla religii katolickiej ma treść wiary. Jej synteza znajduje wyraz w wyznaniu wiary. $Z$ przyjętych prawd wiary wynikają zasady moralne, którymi człowiek wierzący powinien posługiwać się w życiu codziennym. Religia nie jest tylko intelektualnym odniesieniem do rzeczywistości nadprzyrodzonej, ale domaga się aktów religijnych wobec Boga, które znajdują wyraz w praktykach religijnych. Wszystkie te zakresy religii katolickiej są wartościami ${ }^{20}$.

17 Por. Morawski, Monografia, 322-326.

18 Por. Kazimierz Skoczylas, Wartości religijno-moralne młodzieży ponadgimnazjalnej Kujaw wschodnich (Włocławek: Wydawnictwo Duszpasterstwa Rolników, 2016), 73-74.

19 Tamże, 86-87.

${ }^{20}$ Dla celów badawczych przyjęto operacyjną definicję wartości. Wartości to „odziedziczone przez osoby w procesie socjalizacji, w kulturowym kontekście określonego społeczeństwa, zinternalizowane standardy, które służą jako kryteria ocen i preferencji faktów 


\section{a) ogólne odniesienie do religii katolickiej}

Gdy uwzględni się odpowiedzi na pytanie, co stanowi podstawę wiary (por. tab. 1), to zauważa się znaczący udział wypowiedzi podkreślających tradycję i wychowanie w rodzinie.

Tabela 1. Podstawa wiary a płeć respondenta

\begin{tabular}{|l|c|c|c|}
\hline \multirow{2}{*}{\multicolumn{1}{|c|}{ Podstawa wiary }} & \multirow{2}{*}{$\begin{array}{c}\text { Ogółem } \\
(\mathrm{L}=864)\end{array}$} & $\begin{array}{c}\text { Płeć respondenta } \\
(\mathrm{L}=493)\end{array}$ & $\begin{array}{c}\text { mężczyzna } \\
(\mathrm{L}=371)\end{array}$ \\
\cline { 2 - 4 } & \multicolumn{3}{|c|}{ w procentach } \\
\hline Ogółem & 100,0 & 100,0 & 100,0 \\
\hline Osobiste przemyślenia i przekonania & 23,3 & 21,9 & 25,1 \\
\hline Uczęszczanie do Kościoła & 12,7 & 14,8 & 10,0 \\
\hline Wpływ lektur & 1,0 & 1,0 & 1,1 \\
\hline Tradycja i wychowanie w rodzinie & 32,4 & 34,1 & 30,2 \\
\hline Przeżycia i doświadczenia życiowe & 7,5 & 8,9 & 5,7 \\
\hline Tradycja sąsiedzka i środowiskowa & 0,6 & 0,6 & 0,5 \\
\hline Inne & 0,8 & 0,2 & 1,6 \\
\hline Brak danych & 21,6 & 18,5 & 25,9 \\
\hline
\end{tabular}

Źródło: badania własne.

Wśród respondentów dominuje przekonanie, że podstawą ich wiary jest tradycja i wychowanie w rodzinie $(32,4 \%)$ oraz uczęszczanie do kościoła $(12,7 \%)$. Łącznie wpływ chrześcijańskiego środowiska uwypukliło 45,1\% badanych.

Młodzież, porównując swoją religijność z religijnością rodziców, podkreśliła rolę matki w wychowaniu religijnym. Mniejsza jest obecność ojca

społecznych, opinii, przekonań oraz zasad postępowania”. Por. Kazimierz Ryczan, Wartości katolików a typ środowiska miejskiego (Lublin: Redakcja Wydawnictw Katolickiego Uniwersytetu Lubelskiego, 1992), 25-26. 
w tym procesie. Stąd najczęściej respondenci odpowiadali, że ich religijność jest większa od religijności ojca $(29,5 \%)$ bądź że jest taka sama $(29,6 \%)$ (por. tab. 2).

Tabela 2. Własna religijność w odniesieniu do religijności ojca a płeć respondenta

\begin{tabular}{|l|c|c|c|}
\hline \multirow{2}{*}{$\begin{array}{l}\text { Własna religijność w odniesieniu } \\
\text { do religijności ojca }\end{array}$} & \multirow{2}{*}{$\begin{array}{c}\text { Ogółem } \\
(\mathrm{L}=864)\end{array}$} & \begin{tabular}{c}
$|c|$ \\
kobieta \\
\cline { 3 - 4 }
\end{tabular} & \multicolumn{3}{|c|}{ w proces respontach } & $\begin{array}{c}\text { mężczyzna } \\
(\mathrm{L}=371)\end{array}$ \\
\cline { 2 - 4 } & 100,0 & 100,0 & 100,0 \\
\hline Ogółem & 21,8 & 17,2 & 27,8 \\
\hline Mniejsza & 29,5 & 37,5 & 18,9 \\
\hline Większa & 29,6 & 28,0 & 31,8 \\
\hline Taka sama & 18,5 & 16,4 & 21,3 \\
\hline Trudno mi powiedzieć & 0,6 & 0,8 & 0,3 \\
\hline Brak danych & & & \\
\hline
\end{tabular}

Źródło: badania własne.

Tabela 3. Znaczenie religii w życiu respondentów a płeć respondenta

\begin{tabular}{|l|c|c|c|}
\hline \multirow{2}{*}{$\begin{array}{l}\text { Znaczenie religii } \\
\text { w życiu respondentów }\end{array}$} & \multirow{2}{*}{$\begin{array}{c}\text { Ogółem } \\
(\mathrm{L}=864)\end{array}$} & $\begin{array}{c}\text { kobieta } \\
(\mathrm{L}=493)\end{array}$ & $\begin{array}{c}\text { mężczyzna } \\
(\mathrm{L}=371)\end{array}$ \\
\cline { 2 - 4 } & \multicolumn{3}{|c|}{ W procentach } \\
\hline Ogółem & 100,0 & 100,0 & 100,0 \\
\hline Bardzo duże & 16,1 & 19,1 & 12,1 \\
\hline Duże & 32,8 & 35,7 & 28,8 \\
\hline Niezbyt duże & 20,8 & 19,9 & 22,1 \\
\hline Małe & 7,8 & 6,1 & 10,0 \\
\hline Bardzo małe & 5,6 & 4,1 & 7,5 \\
\hline Żadne & 6,8 & 5,9 & 8,1 \\
\hline
\end{tabular}


Tabela 3. Znaczenie religii w życiu respondentów a płeć respondenta (cd.)

\begin{tabular}{|l|c|c|c|}
\hline \multirow{2}{*}{$\begin{array}{c}\text { Znaczenie religii w życiu } \\
\text { respondentów }\end{array}$} & \multirow{2}{*}{$\begin{array}{c}\text { Ogółem } \\
(\mathrm{L}=864)\end{array}$} & $\begin{array}{c}\text { kobieta } \\
(\mathrm{L}=493)\end{array}$ & $\begin{array}{c}\text { mężczyzna } \\
(\mathrm{L}=371)\end{array}$ \\
\cline { 2 - 4 } & \multicolumn{3}{|c|}{ W procentach } \\
\hline Trudno mi powiedzieć & 9,6 & 8,5 & 11,1 \\
\hline Brak danych & 0,6 & 0,8 & 0,3 \\
\hline
\end{tabular}

Źródło: badania własne.

Ludzie przypisują zwykle religii określone znaczenie. Osoby religijne zazwyczaj przypisują jej dużą wagę. Ci, którzy są mniej religijni, nie przypisują do niej tak wielkiego znaczenia. Badana młodzież (tab. 3) ma zróżnicowane oceny. Największa część (48,9\%) przypisuje religii duże i bardzo duże znaczenie. W grupie osób, dla których religia jest ważna, kobiety $(54,8 \%)$ częściej niż mężczyźni (40,9\%) przypisują jej duże i bardzo duże znaczenie. $\mathrm{Z}$ tabeli wynika też, że dla co piątej osoby religia nie przedstawia wielkiej wartości.

\section{b) Stosunek do wybranych praktyk religijnych}

Dla wychowania religijnego istotne znaczenie ma uczestnictwo w życiu religijnym. Dla kształtowania postaw katolickich bardzo istotne znaczenie ma uczestnictwo w Mszy Świętej, spowiedź oraz udział w lekcji religii. Liturgia Mszy Świętej niedzielnej przewiduje homilię, która na bieżąco przedstawia treść wiary wraz z wymaganiami moralnymi. Spowiedź daje szansę oceny własnego zachowania z perspektywy wymagań moralnych stawianych przez Chrystusa. Ona mobilizuje do wysiłku w realizacji dobra. Katecheza zaś daje możliwość systematycznego rozszerzania treści wiary i płynących z niej wymagań moralnych.

Udział w Mszy Świętej wśród młodzieży Kujaw wschodnich jest zróżnicowany. Przedstawia to tabela 4. Trzy pierwsze kategorie, które świadczą o dość gorliwym uczestnictwie w życiu Kościoła, obejmują 51,8\%. Kolejne kategorie (4-6) obejmują 38\%. Ta grupa znacznie rzadziej utrzymuje kontakt z Kościołem. 
Tabela 4. Częstotliwość uczestnictwa w Mszy Świętej w ciągu roku a płeć respondenta

\begin{tabular}{|l|c|c|c|}
\hline \multirow{2}{*}{$\begin{array}{l}\text { Częstotliwość uczestnictwa } \\
\text { w Mszy Świętej w ciągu roku }\end{array}$} & \multirow{2}{*}{$\begin{array}{c}\text { Ogółem } \\
(\mathrm{L}=864)\end{array}$} & $\begin{array}{c}\text { kobieta } \\
(\mathrm{L}=493)\end{array}$ & $\begin{array}{c}\text { mężczyzna } \\
(\mathrm{L}=371)\end{array}$ \\
\cline { 3 - 4 } & & \multicolumn{3}{|c|}{ w procentach } \\
\hline Ogółem & 100,0 & 100,0 & 100,0 \\
\hline W każdą niedzielę & 15,0 & 16,2 & 13,5 \\
\hline Prawie w każdą niedzielę & 21,6 & 27,4 & 14,0 \\
\hline Około 1-2 razy w miesiącu & 15,2 & 14,4 & 16,2 \\
\hline Tylko w wielkie święta & 17,7 & 15,2 & 21,0 \\
\hline Tylko z okazji ślubu, pogrzebu & 13,8 & 13,0 & 14,8 \\
\hline Wcale & 6,5 & 4,1 & 9,7 \\
\hline Trudno mi powiedzieć & 6,7 & 6,3 & 7,3 \\
\hline Brak danych & 3,5 & 3,4 & 3,5 \\
\hline
\end{tabular}

Źródło: K. Skoczylas, Wartości religijno-moralne młodzieży ponadgimnazjalnej Kujaw wschodnich (Włocławek: Wydawnictwo Duszpasterstwa Rolników, 2016), 167.

Kościół zobowiązuje swoich wiernych do spowiedzi przynajmniej raz w roku w okresie wielkanocnym. Zachęca się jednak do częstej spowiedzi. Postawy wobec spowiedzi przedstawia tabela 5.

Tabela 5. Częstotliwość korzystania z sakramentu pokuty a stałe miejsce zamieszkania

\begin{tabular}{|l|c|c|c|c|c|}
\hline \multirow{2}{*}{$\begin{array}{c}\text { Częstotliwość } \\
\text { korzystania z sakramentu } \\
\text { pokuty }\end{array}$} & Ogółem & \multicolumn{4}{|c|}{ Stałe miejsce zamieszkania } \\
\cline { 3 - 6 } & $(\mathrm{L}=863)$ & $\begin{array}{c}\text { Wieś } \\
(\mathrm{L}=338)\end{array}$ & $\begin{array}{c}\text { Małe miasto } \\
(\mathrm{L}=118)\end{array}$ & $\begin{array}{c}\text { Srednie } \\
\text { miasto } \\
(\mathrm{L}=128)\end{array}$ & $\begin{array}{c}\text { Duże } \\
\text { miasto } \\
(279)\end{array}$ \\
\cline { 2 - 7 } & \multicolumn{5}{|c|}{ w procentach } \\
\hline Ogółem & 100,0 & 100,0 & 100,0 & 100,0 & 100,0 \\
\hline Raz w miesiącu & 21,9 & 29,3 & 21,2 & 21,9 & 13,3 \\
\hline Kilka razy w miesiącu & 2,7 & 2,7 & 2,5 & 2,3 & 2,9 \\
\hline
\end{tabular}


Tabela 5. Częstotliwość korzystania z sakramentu pokuty (cd.)

\begin{tabular}{|l|c|c|c|c|c|}
\hline \multirow{2}{*}{$\begin{array}{c}\text { Częstotliwość } \\
\text { korzystania z sakramentu } \\
\text { pokuty }\end{array}$} & \multirow{2}{*}{$\begin{array}{c}\text { Ogółem } \\
(\mathrm{L}=863)\end{array}$} & $\begin{array}{c}\text { Wieś } \\
(\mathrm{L}=338)\end{array}$ & $\begin{array}{c}\text { Małe miasto } \\
(\mathrm{L}=118)\end{array}$ & $\begin{array}{c}\text { Średnie } \\
\text { miasto } \\
(\mathrm{L}=128)\end{array}$ & $\begin{array}{c}\text { Duże } \\
\text { miasto } \\
(279)\end{array}$ \\
\cline { 3 - 7 } & \multicolumn{5}{|c|}{ w procentach } \\
\hline Raz w roku & 30,0 & 35,5 & 24,6 & 30,5 & 25,4 \\
\hline Raz na kilka lat & 16,8 & 8,6 & 22,9 & 14,8 & 25,1 \\
\hline Ani razu od dzieciństwa & 2,7 & 1,8 & 2,5 & 2,3 & 3,9 \\
\hline Wcale nie przystępuję & 7,0 & 2,4 & 5,1 & 9,4 & 12,2 \\
\hline Trudno mi powiedzién & 16,5 & 16,3 & 20,3 & 17,2 & 14,7 \\
\hline Brak danych & 2,5 & 3,6 & 0,8 & 1,6 & 2,5 \\
\hline
\end{tabular}

Źródło: K. Skoczylas, Wartości, 173-174.

Większość młodzieży $(54,6 \%)$ dość regularnie podejmuje trud formacji własnego sumienia. Najczęściej są to osoby ze wsi (kategorie 1-3 obejmują $67,5 \%$ ), a stosukowo rzadko $\mathrm{z}$ dużego miasta (te same kategorie obejmują $41,4 \%)$.

Udział w katechezie jest również zróżnicowany. Ilustruje to tabela 6 .

Tabela 6. Udział w katechizacji a płeć respondenta

\begin{tabular}{|l|c|c|c|}
\hline \multirow{2}{*}{ Udział w katechizacji } & \multirow{2}{*}{$\begin{array}{c}\text { Ogółem } \\
(\mathrm{L}=864)\end{array}$} & $\begin{array}{c}\text { kobieta } \\
(\mathrm{L}=493)\end{array}$ & $\begin{array}{c}\text { mężczyzna } \\
(\mathrm{L}=371)\end{array}$ \\
\cline { 2 - 4 } & \multicolumn{3}{|c|}{ w procentach } \\
\hline Ogółem & 100,0 & 100,0 & 100,0 \\
\hline Tak, regularnie & 67,2 & 74,0 & 58,2 \\
\hline Nie, nieregularnie & 10,5 & 8,5 & 13,2 \\
\hline Wcale nie & 6,8 & 3,7 & 11,1 \\
\hline
\end{tabular}


Tabela 6. Udział w katechizacji a płeć respondenta (cd.)

\begin{tabular}{|l|c|c|c|}
\hline \multirow{2}{*}{ Udział w katechizacji } & \multirow{2}{*}{$\begin{array}{c}\text { Ogółem } \\
(\mathrm{L}=864)\end{array}$} & $\begin{array}{c}\text { kobieta } \\
(\mathrm{L}=493)\end{array}$ & $\begin{array}{c}\text { mężczyzna } \\
(\mathrm{L}=371)\end{array}$ \\
\cline { 2 - 4 } & \multicolumn{3}{|c|}{ w procentach } \\
\cline { 2 - 4 } & 13,2 & 11,2 & 15,9 \\
\hline Trudno mi powiedzieć & 2,2 & 2,6 & 1,6 \\
\hline
\end{tabular}

Źródło: K. Skoczylas, Wartości, 184.

Systematycznie w katechezie uczestniczy $67,2 \%$, jednak bardziej regularnie uczestniczą dziewczęta (74\%) niż chłopcy $(58,2 \%)$.

Przytoczone wyżej tabele ujawniają, że więcej niż połowa badanych uczestniczy w życiu religijnym. Oni mają największą szansę formowania życia religijnego przez wspólnotę Kościoła. Można powiedzieć, że Kościół zachowuje znaczący wpływ wychowawczy w tym środowisku.

\section{c) Odniesienie do podstawowych norm moralnych}

Dla zachowań określonych przez wiarę istotne znaczenie ma kodeks postepowania moralnego. Fundamentem moralności chrześcijańskiej jest Dekalog. Poniższa tabela ilustruje akceptację poszczególnych przykazań Dekalogu. Jest to zestawienie sumujące, które pozwala dostrzec całościowy obraz akceptacji Bożych przykazań.

Tabela 7. Akceptacja Dekalogu

\begin{tabular}{|l|c|}
\hline \multicolumn{1}{|c|}{ Przykazanie } & $\begin{array}{c}\text { Akceptacja } \\
\text { (całkowita + częściowa) }\end{array}$ \\
\hline Pierwsze przykazanie & $63,1 \%$ \\
\hline Drugie przykazanie & $51,3 \%$ \\
\hline Trzecie przykazanie & $62,8 \%$ \\
\hline Czwarte przykazanie & $75,3 \%$ \\
\hline Piąte przykazanie & $75,1 \%$ \\
\hline
\end{tabular}


Tabela 7. Akceptacja Dekalogu (cd.)

\begin{tabular}{|l|c|}
\hline \multicolumn{1}{|c|}{ Przykazanie } & $\begin{array}{c}\text { Akceptacja } \\
\text { (całkowita + częściowa) }\end{array}$ \\
\hline Szóste przykazanie & $69,7 \%$ \\
\hline Siódme przykazanie & $73,7 \%$ \\
\hline Ósme przykazanie & $69,9 \%$ \\
\hline Dziewiąte przykazanie & 68,4 \\
\hline Dziesiąte przykazanie & $67,1 \%$ \\
\hline
\end{tabular}

Źródło: K. Skoczylas, Wartości, 267.

Najwyższy poziom akceptacji zyskuje przykazanie czwarte (Czcij ojca swego i matkę swoją - 75,3\%), piąte (Nie zabijaj- 75,1\%), siódme (Nie kradnij $-73,7 \%)$. Najniższy poziom akceptacji osiąga przykazanie drugie (51,3\%). Można więc stwierdzić, że niemal 3/4 młodzieży akceptuje religijne normy moralne.

\section{d) stosowanie norm moralnych w wybranych sytuacjach życia codziennego}

O odniesieniu młodzieży do religii katolickiej świadczy jej sposób wartościowania w wielu codziennych sytuacjach. Zakłada się, że młody katolik w ocenie zachowań moralnych posługuje się normami moralnymi stale przypominanymi $\mathrm{w}$ różnych okolicznościach przez Kościół katolicki. To, jaki wpływ mają normy na jego oceny, pozwalają stwierdzić przeprowadzone badania. Aby to zilustrować, zostaną przedstawione oceny wybranych sytuacji życiowych: okradanie własnej rodziny, czego przejawem jest wyjmowanie rodzicom pieniędzy z portfela, okradanie społeczeństwa wyrażające się przez oszustwa podatkowe, brak troski o własne życie i zdrowie, co przejawia się w nadużywaniu alkoholu i narkotyków, a także zagadnienia ze sfery seksualnej człowieka, jak przedmałżeńskie stosunki seksualne i zdrada współmałżonka. 
Tabela 8. Wyjmowanie pieniędzy rodzicom a płeć respondenta

\begin{tabular}{|l|c|c|c|}
\hline \multirow{2}{*}{ Wyjmowanie pieniędzy rodzicom } & \multirow{2}{*}{$\begin{array}{c}\text { Ogółem } \\
(\mathrm{L}=864)\end{array}$} & $\begin{array}{c}\text { Pobieta } \\
(\mathrm{L}=493)\end{array}$ & $\begin{array}{c}\text { mężczyzna } \\
(\mathrm{L}=371)\end{array}$ \\
\cline { 2 - 4 } & \multicolumn{3}{|c|}{ w procentach } \\
\hline Ogółem & 100,0 & 100,0 & 100,0 \\
\hline Całkowicie nieusprawiedliwione & 36,9 & 38,1 & 35,3 \\
\hline Częściowo nieusprawiedliwione & 15,0 & 15,2 & 14,8 \\
\hline W małym stopniu nieusprawiedliwione & 17,0 & 18,3 & 15,4 \\
\hline Obojętne & 16,7 & 16,0 & 17,5 \\
\hline W małym stopniu usprawiedliwione & 5,3 & 4,7 & 6,2 \\
\hline Częściowo usprawiedliwione & 2,9 & 2,6 & 3,2 \\
\hline Całkowicie usprawiedliwione & 3,7 & 3,2 & 4,3 \\
\hline Brak danych & 2,4 & 1,8 & 3,2 \\
\hline
\end{tabular}

Źródło: K. Skoczylas, Wartości, 267.

Tabela 9. Oszustwa podatkowe a płeć respondenta

\begin{tabular}{|l|c|c|c|}
\hline \multirow{2}{*}{\multicolumn{1}{c|}{ Oszustwa podatkowe }} & \multirow{2}{*}{$\begin{array}{c}\text { Ogółem } \\
(\mathrm{L}=864)\end{array}$} & $\begin{array}{c}\text { Pobieta } \\
(\mathrm{L}=493)\end{array}$ & $\begin{array}{c}\text { mężczyzna } \\
(\mathrm{L}=371)\end{array}$ \\
\cline { 2 - 4 } & \multicolumn{3}{|c|}{ w procentach } \\
\hline Ogółem & 100,0 & 100,0 & 100,0 \\
\hline Całkowicie nieusprawiedliwione & 52,7 & 59,0 & 44,2 \\
\hline Częściowo nieusprawiedliwione & 13,2 & 15,4 & 10,2 \\
\hline W małym stopniu nieusprawiedliwione & 11,5 & 9,3 & 14,3 \\
\hline Obojętne & 12,3 & 9,9 & 15,4 \\
\hline W małym stopniu usprawiedliwione & 2,2 & 1,4 & 3,2 \\
\hline Częściowo usprawiedliwione & 2,0 & 1,4 & 2,7 \\
\hline
\end{tabular}


Tabela 9. Oszustwa podatkowe a płeć respondenta (cd.)

\begin{tabular}{|c|c|c|c|}
\hline \multirow{3}{*}{ Oszustwa podatkowe } & \multirow{2}{*}{$\begin{array}{c}\text { Ogółem } \\
(\mathrm{L}=864)\end{array}$} & \multicolumn{2}{|c|}{ Płeć respondenta } \\
\hline & & $\begin{array}{c}\text { kobieta } \\
(\mathrm{L}=493)\end{array}$ & $\begin{array}{c}\text { mężczyzna } \\
(\mathrm{L}=371)\end{array}$ \\
\hline & \multicolumn{3}{|c|}{ w procentach } \\
\hline Całkowicie usprawiedliwione & 3,6 & 1,4 & 6,5 \\
\hline Brak danych & 2,7 & 2,0 & 3,5 \\
\hline
\end{tabular}

Źródło: K. Skoczylas, Wartości, 262.

Większość badanych (kategorie 1-3 w tabeli 8 obejmuje 68,9\%) okradanie własnej rodziny ocenia negatywnie. Jednak niemal co czwarty (kategorie 5-7, co stanowi $24,9 \%$ ) jest skłonny zaakceptować to zachowanie. Stopień akceptacji dla okradania rodziców ma różne nasilenie. Są tacy, którzy w takim zachowaniu nie widzą zła - ,całkowicie usprawiedliwione” (2,9\%), po takich, którzy mają świadomość, że takiego zachowania nie da się do końca usprawiedliwić. Oni wybierali kategorię „,w małym stopniu usprawiedliwione" $(16,7 \%)$.

Okradanie społeczeństwa i państwa przejawia się przez oszustwa podatkowe. Postawy młodych wobec tego opisuje tabela 9.

Większość młodzieży (kategorie 1-3 w tabeli 9 obejmują 77,4\%) ocenia oszustwa podatkowe negatywnie. Są one w ich ocenie nieusprawiedliwione, przy czym ponad połowa $(52,7 \%)$ uznaje takie zachowanie za ,całkowicie nieusprawiedliwione". Z kolei 7,8\% to zachowanie uznaje za całkowicie dopuszczalne.

Porównanie tych dwóch rodzajów kradzieży ujawnia, że młodzież jest bardziej radykalna w ocenach, które mają charakter społeczny, a mniej radykalna, gdy odnoszą się do rodziny. W obu przypadkach ponad połowa badanych całkowicie potępia takie formy zachowania.

Przykazanie „nie zabijaj” zobowiązuje również do troski o swoje życie i zdrowie. Stosunek do nadużywania alkoholu, które jest brakiem tej troski, przedstawia tabela 10 .

Nadużywanie alkoholu przez większość młodzieży (kategorie 1-3 w tabeli 10 obejmują 54,2\%) oceniane jest jako zachowanie moralnie złe. Jednak 19,8\% uznaje takie postępowanie za dobre moralnie. Należy pamiętać, że na podstawie raportu Państwowej Agencji Rozwiązywania Problemów Alkoholowych w roku $2011 \mathrm{w}$ grupie młodzieży ponadgimnazjalnej w tym okresie 
odnotowywano wysoki odsetek tych, którzy w ostatnim miesiącu pili wódkę $(62,5 \%)^{21}$.

Tabela 10. Ocena nadużywania alkoholu a płeć respondenta

\begin{tabular}{|c|c|c|c|}
\hline \multirow{3}{*}{ Ocena nadużywania alkoholu } & \multirow{2}{*}{$\begin{array}{c}\text { Ogółem } \\
(\mathrm{L}=864)\end{array}$} & \multicolumn{2}{|c|}{ Płeć respondenta } \\
\hline & & $\begin{array}{l}\text { kobieta } \\
(\mathrm{L}=493)\end{array}$ & $\begin{array}{c}\text { mężczyzna } \\
(\mathrm{L}=371)\end{array}$ \\
\hline & \multicolumn{3}{|c|}{ w procentach } \\
\hline Ogółem & 100,0 & 100,0 & 100,0 \\
\hline Całkowicie nieusprawiedliwione & 25,8 & 30,2 & 19,9 \\
\hline Częściowo nieusprawiedliwione & 14,6 & 15,6 & 13,2 \\
\hline W małym stopniu nieusprawiedliwione & 13,8 & 14,0 & 13,5 \\
\hline Obojętne & 22,5 & 22,5 & 22,4 \\
\hline W małym stopniu usprawiedliwione & 7,3 & 6,7 & 8,1 \\
\hline Częściowo usprawiedliwione & 5,0 & 3,2 & 7,3 \\
\hline Całkowicie usprawiedliwione & 7,5 & 4,5 & 11,6 \\
\hline Brak danych & 3,6 & 3,2 & 4,0 \\
\hline
\end{tabular}

Źródło: K. Skoczylas, Wartości, 262.

W społeczeństwie dość częste jest używanie narkotyków. Młodzież także coraz chętniej sięga po narkotyki. Tabela 11 przedstawia oceny używania narkotyków.

Jak wynika z tabeli 11, większość młodzieży (w tabeli 11 kategorie 1-3 obejmują $69,2 \%$ badanych) ocenia zażywanie narkotyków jako działanie moralnie złe, $10,6 \%$ badanych korzystanie z nich ocenia zaś jako dobre. Z badań Państwowej Agencji Rozwiązywania Problemów Alkoholowych opublikowanych w 2011 r. wynika, że wśród chłopców w ciągu ostatnich 12 miesięcy sięgało po haszysz i marihuanę 36,4\% badanych, a wśród dziew-

${ }^{21}$ Janusz Sierosławski, Używanie alkoholu i narkotyków przez młodzież szkolną. Raport z ogólnopolskich badań ankietowych zrealizowanych w 2011 r. (Warszawa: Krajowe Biuro ds. Przeciwdziałania Narkomanii. Państwowa Agencja Rozwiązywania Problemów Alkoholowych. Instytut Psychiatrii i Neurologii, 2011), 23. 
cząt 20,2\% $\%^{22}$. Przytoczone dane pozwalają zrozumieć dość wysoki poziom akceptacji dla zażywania narkotyków.

Tabela 11. Zażywanie narkotyków a płeć respondenta

\begin{tabular}{|c|c|c|c|}
\hline \multirow{3}{*}{ Zażywanie narkotyków } & \multirow{2}{*}{$\begin{array}{c}\text { Ogółem } \\
(\mathrm{L}=864)\end{array}$} & \multicolumn{2}{|c|}{ Płeć respondenta } \\
\hline & & $\begin{array}{l}\text { kobieta } \\
(\mathrm{L}=493)\end{array}$ & $\begin{array}{c}\text { mężczyzna } \\
(\mathrm{L}=371)\end{array}$ \\
\hline & \multicolumn{3}{|c|}{ w procentach } \\
\hline Ogółem & 100,0 & 100,0 & 100,0 \\
\hline Całkowicie nieusprawiedliwione & 49,3 & 54,0 & 43,1 \\
\hline Częściowo nieusprawiedliwione & 12,4 & 13,0 & 11,6 \\
\hline W małym stopniu nieusprawiedliwione & 7,5 & 8,3 & 6,5 \\
\hline Obojętne & 17,0 & 14,0 & 21,0 \\
\hline W małym stopniu usprawiedliwione & 3,6 & 3,7 & 3,5 \\
\hline Częściowo usprawiedliwione & 3,2 & 2,6 & 4,0 \\
\hline Całkowicie usprawiedliwione & 3,9 & 2,2 & 6,2 \\
\hline Brak danych & 3,0 & 2,2 & 4,0 \\
\hline
\end{tabular}

Źródło: K. Skoczylas, Wartości, 252.

Przedmałżeńskie stosunki seksualne są negatywnie oceniane w nauczaniu Kościoła. Poglądy młodzieży na ten temat ilustruje tabela 12.

Tabela 12. Przedmałżeńskie stosunki seksualne a płeć respondenta

\begin{tabular}{|l|c|c|c|}
\hline \multirow{2}{*}{ Przedmałżeńskie stosunki seksualne } & \multirow{2}{*}{$\begin{array}{c}\text { Ogółem } \\
(\mathrm{L}=864)\end{array}$} & $\begin{array}{c}|c| \\
\text { Pobiéta } \\
(\mathrm{L}=493)\end{array}$ & $\begin{array}{c}\text { mężczyzna } \\
(\mathrm{L}=371)\end{array}$ \\
\cline { 2 - 4 } & \multicolumn{3}{|c|}{ w procentach } \\
\hline Ogółem & 100,0 & 100,0 & 100,0 \\
\hline Całkowicie nieusprawiedliwione & 10,0 & 10,5 & 9,2 \\
\hline
\end{tabular}

${ }^{22}$ Sierosławski, Używanie, 47. 
Tabela 12. Przedmałżeńskie stosunki seksualne a płeć respondenta (cd.)

\begin{tabular}{|l|c|c|c|}
\hline \multirow{2}{*}{ Przedmałżeńskie stosunki seksualne } & \multirow{2}{*}{$\begin{array}{c}\text { Ogółem } \\
(\mathrm{L}=864)\end{array}$} & \begin{tabular}{c}
$|c|$ \\
\cline { 3 - 4 }
\end{tabular} & \multicolumn{3}{|c|}{ Płeć respondenta } \\
\cline { 2 - 4 } & \multicolumn{2}{|c|}{ w procentach } & $\begin{array}{c}\text { mężczyzna } \\
(\mathrm{L}=371)\end{array}$ \\
\hline Częściowo nieusprawiedliwione & 5,7 & 7,7 & 3,0 \\
\hline W małym stopniu nieusprawiedliwione & 5,8 & 5,9 & 5,7 \\
\hline Obojętne & 27,2 & 30,0 & 23,5 \\
\hline W małym stopniu usprawiedliwione & 7,3 & 7,7 & 6,8 \\
\hline Częściowo usprawiedliwione & 9,2 & 10,5 & 7,3 \\
\hline Całkowicie usprawiedliwione & 31,6 & 25,4 & 40,0 \\
\hline Brak danych & 3,2 & 2,2 & 4,6 \\
\hline
\end{tabular}

Źródło: K. Skoczylas, Wartości, 269-270.

Przedmałżeńskie stosunki seksualne (w tabeli 12 kategoria 1-3) potępia $21,5 \%$ badanych. Natomiast 48,1\% (tabela 12 kategoria 4-6) traktuje je jako działanie usprawiedliwione. Warto zauważyć, że co trzeci z badanych uważa to za całkowicie usprawiedliwione. To wskazuje na wysoki poziom przyzwolenia społecznego dla tego zachowania mimo negatywnej jego oceny w nauczaniu Kościoła.

Małżeństwo w nauczaniu Kościoła domaga się zachowania wierności małżeńskiej. Jej zaprzeczeniem jest zdrada małżeńska. Poglądy młodzieży na temat zdrady przedstawia tabela 13 .

Tabela13. Ocena zdrady małżeńskiej a płeć respondenta

\begin{tabular}{|l|c|c|c|}
\hline \multirow{2}{*}{ Ocena zdrady małżeńskiej } & \multirow{2}{*}{$\begin{array}{c}\text { Ogółem } \\
(\mathrm{L}=864)\end{array}$} & $\begin{array}{c}\text { kobieta } \\
(\mathrm{L}=493)\end{array}$ & $\begin{array}{c}\text { mężczyzna } \\
(\mathrm{L}=371)\end{array}$ \\
\cline { 2 - 4 } & \multicolumn{3}{|c|}{ W procentach } \\
\cline { 2 - 4 } & \multicolumn{3}{|c|}{ Ołeć respondenta } \\
\hline Ogółem & 100,0 & 100,0 & 100,0 \\
\hline Dozwolone & 6,0 & 4,9 & 7,5 \\
\hline
\end{tabular}


Tabela13. Ocena zdrady małżeńskiej a płeć respondenta (cd.)

\begin{tabular}{|l|c|c|c|}
\hline \multirow{2}{*}{ Ocena zdrady małżeńskiej } & \multirow{2}{*}{$\begin{array}{c}\text { Ogółem } \\
(\mathrm{L}=864)\end{array}$} & $\begin{array}{c}\text { kobieta } \\
(\mathrm{L}=493)\end{array}$ & $\begin{array}{c}\text { mężczyzna } \\
(\mathrm{L}=371)\end{array}$ \\
\cline { 2 - 4 } & \multicolumn{3}{|c|}{ W procentach } \\
\hline To zależy & 13,8 & 11,2 & 17,3 \\
\hline Niedozwolone & 66,0 & 75,1 & 53,9 \\
\hline Nie umiem powiedzieć & 8,8 & 5,7 & 12,9 \\
\hline Brak danych & 5,4 & 3,2 & 8,4 \\
\hline
\end{tabular}

Źródło: K. Skoczylas, Wartości, 233.

Większość młodzieży (66\%) jest przekonana, że zdrada małżeńska jest zachowaniem niedopuszczalnym w małżeństwie. Znacznie częściej takie oceny ujawniają kobiety $(75,1 \%)$ niż mężczyźni $(53,9 \%)$. Jednak 6\% sądzi, że to zachowanie jest całkowicie dozwolone. Częściej akceptują to mężczyźni (7,5\%) niż kobiety (4,9\%). Dość znaczna grupa $(13,8 \%)$ ocenę tego zachowania uzależnia od występujących okoliczności. Niemal 20\% badanych jest gotowych zaakceptować zdradę w małżeństwie.

\section{Wnioski}

Stosunek młodzieży pochodzącej z Kujaw wschodnich do wartości kształtuje się pod wpływem wartości przekazywanych przez starsze pokolenie w rodzinie, dzięki oddziaływaniu Kościoła, na skutek wartości pielęgnowanych w życiu narodowym i tych wartości, które obecne są w środowisku Kujaw. Jest to region rolniczy. Zatem wartości ważne w rolnictwie kształtują również jej system wartości.

Ludność Kujaw wschodnich w zasadniczej mierze jest ludnością należącą do wyznania katolickiego. Młodzież mieszkająca na tym terenie wychowuje się w rodzinach katolickich. Religia jest w nich dość ważna. Stąd religijność jest obecna w życiu rodzin. O religijności młodego pokolenia w znacznej mierze przesądza tradycja i wychowanie w rodzinie. Dla religijności młodzieży ważna jest religijność matki, która bardziej niż ojciec jest obecna w wychowaniu religijnym dzieci. 
Religijność młodego pokolenia na Kujawach wschodnich jest kształtowana w znacznej mierze przez uczestnictwo w życiu religijnym Kościoła katolickiego. Temu rozwojowi sprzyjają praktyki religijne. W Mszy Świętej w miarę systematycznie uczestniczy nieco ponad połowa młodych $(51,8 \%)$. Przez systematyczną spowiedź kształtuje swoje sumienie 54,6\%. W lekcji religii uczestniczy $67,2 \%$.

Religijność zawiera $\mathrm{w}$ sobie postępowanie moralne zgodne $\mathrm{z}$ wiarą. Fundamentem dla tego postępowania jest kodeks moralny, oparty na Bożych przykazaniach. Z przeprowadzonych badań wynika, że trzy czwarte młodzieży akceptuje Boże przykazania.

Większość zachowań moralnych pojawiająca się w codziennym życiu jest oceniana zgodnie z Dekalogiem. Są jednak takie obszary ludzkiego postępowania, które są wartościowane niezależnie od Dekalogu. Takim obszarem, który jest oceniany niezależnie od przykazań, jest obszar niektórych zachowań seksualnych. Dotyczy to szczególnie przedmałżeńskich stosunków seksualnych. Ten stan rzeczy wymaga wzmożonego wysiłku duszpasterskiego we wspólnocie Kościoła.

Wpływ współczesnej kultury i różne przemiany społeczne powodują $\mathrm{z}$ jednej strony umocnienie tożsamości chrześcijańskiej, a z drugiej strony wśród pewnej grupy młodych powołują one zagubienie własnej tożsamości. Stan tej drugiej grupy jest wyzwaniem dla współczesnego duszpasterstwa w Polsce.

\section{Young People Reference to the Catholic Religion in Eastern Kujawy Region (Summary)}

Eastern Kuyavia's young people are usually brought up in Catholic families. The acceptance of the values that Christianity brings has an impact on the reference to other people. Catholic families try to impart Catholic values. The Church community supports the educational activity of families. In an adolescence period a personal reference to the Catholic religion is shaped under the influence of the family and the impact of the Church.

Keywords: values; faith; family; young people; religious education/catechesis; pastoral care. 


\section{Odniesienie młodzieży do religii katolickiej na Kujawach wschodnich (Streszczenie)}

Młodzież Kujaw wschodnich wychowuje się zazwyczaj w rodzinach katolickich. Akceptacja wartości, które przynosi chrześcijaństwo, ma wpływ na odniesienie do innych ludzi. Rodziny katolickie starają się przekazać wartości katolickie. Wspólnota Kościoła wspiera aktywność wychowawczą rodzin. W okresie adolescencji pod wpływem rodziny i oddziaływania Kościoła kształtuje się osobiste odniesienie młodych do religii katolickiej.

Słowa kluczowe: wartości; wiara; rodzina; młodzież; katecheza/nauczanie religii; duszpasterstwo.

\section{Bibliografia}

Ciechalski, Arkadiusz. „Cukrownia w Choceniu”. http://www.historycznepapiery.pl/ wp-content/uploads/2015/03/A.-Ciechalski-Cukrownia-w-Choceniu.pdf (dostęp: 04.09.2017).

Ciechalski, Arkadiusz. „Ziemiańska rodzina Kretkowskich z okręgu kowalskiego”. W: Kowal przez wieki, red. Zdzisław J. Zasada, 87-117. Włocławek-Kowal: Włocławskie Towarzystwo Naukowe, 2007.

Dyczewski, Leon. Rodzina, społeczeństwo, państwo. Lublin: Towarzystwo Naukowe Katolickiego Uniwersytetu Lubelskiego, 1994.

Dyczewski, Leon. Rodzina twórca i przekazicielem kultury. Lublin: Towarzystwo Naukowe Katolickiego Uniwersytetu Lubelskiego, 2003.

Dyczewski, Leon. „Święto i jego kulturotwórcza rola”. Kultura i społeczeństwo 2 (2012): 3-16.

Ejsmont, Marek, Beata Kosmalska. „Reklamy a postawy konsumpcyjne dzieci i młodzieży". W: Współczesna młodzież pomiędzy eros a thanatos, red. Jacek Kurzępa, Alicja Lisowska, Agnieszka Pierzchalska, 95-104. Wrocław: Agencja Wydawnicza „ARGI” s.c., 2008.

Godawa, Grzegorz. „Emocjonalne dojrzewanie dzieci i młodzieży w medialnym społeczeństwie". Studia Socialia Cracoviensia 2 (2013): 111-125.

Guldon, Zenon, Jadwiga Muszyńska. „Zasięg gdańskiego i królewieckiego rynku zbożowego a rozwój gospodarki folwarczno-pańszczyźnianej w Rzeczypospolitej w XVI-XVIII wieku". Czasy nowożytne 4 (1998): 141-165. 
Kędzior, Jolanta. „Młodzież jako specyficzna kategoria społeczna”. W: Współczesna młodzież pomiędzy eros a thanatos, red. Jacek Kurzępa, Alicja Lisowska, Agnieszka Pierzchalska, 9-18. Wrocław: Agencja Wydawnicza „ARGI” s.c., 2008.

Kowalska, Małgorzata. „Jadwiga Dziubińska”. http://kobietynawsi.pl/Jadwiga Dziubińska (dostęp: 20.08.2017).

Kujawski, Witold. „Historia Diecezji Włocławskiej”. W: Rocznik Diecezji Włocławskiej, red. Artur Niemira, 41-82. Włocławek: Wydawnictwo Duszpasterstwa Rolników, 2011.

Morawski, Michał. Monografia Włocławka. Włocławek: Włocławskie Wydawnictwo Diecezjalne, 2003.

Ryczan, Kazimierz. Wartości katolików a typ środowiska miejskiego. Lublin: Redakcja Wydawnictw Katolickiego Uniwersytetu Lubelskiego, 1992.

Sierosławski, Janusz. Używanie alkoholu i narkotyków przez młodzież szkolna. Raport z ogólnopolskich badań ankietowych zrealizowanych $w 2011 \mathrm{r}$. Warszawa: Krajowe Biuro ds. Przeciwdziałania Narkomanii. Państwowa Agencja Rozwiązywania Problemów Alkoholowych. Instytut Psychiatrii i Neurologii, 2011.

Skoczylas, Kazimierz. Wartości religijno-moralne młodzieży ponadgimnazjalnej Kujaw wschodnich. Włocławek: Wydawnictwo Duszpasterstwa Rolników, 2016.

Strumska-Cylwik, Longina. „Młodzież w dobie kultury przyzwolenia oraz otwartości «niepohamowanej»/《obojętnej» (pytanie o otwartość w kontekście zjawisk konsumpcjonizmu i konsumeryzmu)". W: Wspótczesna młodzież pomiędzy eros a thanatos, red. Jacek Kurzępa, Alicja Lisowska, Agnieszka Pierzchalska, 83-93. Wrocław: Agencja Wydawnicza „ARGI” s.c., 2008.

Wawrzyniak, Bogdan M. Monografia rolnictwa województwa kujawsko-pomorskiego. Włocławek: Lega - Oficyna Wydawnicza Włocławskiego Towarzystwa Naukowego, 2002. 